\title{
New Sesquiterpene Hydroperoxides with Trypanocidal Activity from Pogostemon cablin
}

\author{
Fumiyuki Kivchi, ${ }^{a}$ Kenji Matsuo, ${ }^{b}$ Michiho Ito, ${ }^{b}$ Tran Kim Qui, ${ }^{c}$ and Gisho HondA ${ }^{*, b}$ \\ ${ }^{a}$ Tsukuba Medicinal Plant Research Station, National Institute of Health Sciences; 1 Hachiman-dai, Tsukuba 305-0843, \\ Japan: ${ }^{b}$ Graduate School of Pharmaceutical Sciences, Kyoto University; 46-29 Yoshida, Sakyo-ku, Kyoto 606-8501, \\ Japan: and ${ }^{c}$ Research Center for Applied Chemistry, Vietnam National University; Ho Chi Min City, Vietnam. \\ Received July 26, 2004; accepted September 7, 2004
}

Trypanocidal constituents of Pogostemon cablin were investigated. Activity guided isolation of the acetone extract resulted in isolation of three new sesquiterpene hydroperoxides $1-3$, together with a known sesquiterpene, patchouli alcohol (4). In vitro minimum lethal concentrations of the hydroperoxides $1-3$ against epimastigotes of Trypanosoma cruzi were $0.84 \mu_{\mathrm{M}}(1), 1.7 \mu_{\mathrm{M}}(2)$ and $1.7 \mu_{\mathrm{M}}$ (3). The activity of the corresponding alcohols and patchouli alcohol was very weak (MLC $>200 \mu \mathrm{M})$.

Key words Pogostemon cablin; Labiatae; sesquiterpene hydroperoxide; trypanocidal constitutent; Trypanosoma cruzi

Pogostemon cablin (BLANCO) BENTH. (Labiatae) is a perennial herb, which has been used as stomachic for indigestion, vomiting and diarrhea, and also for headache and fever in Asian countries. ${ }^{1)}$ In our search for anti-trypanosomal compounds from natural medicines used in Vietnam, ${ }^{2)}$ an acetone extract of this plant showed potent trypanocidal activity against the epimastigotes of Trypanosoma cruzi, the etiologic agent of American trypanosomiasis (Chaga's disease). ${ }^{3)}$ In this paper, we report the isolation and characterization of three new sesquiterpene hydroperoxides $(\mathbf{1}-\mathbf{3})$ together with a known sesquiterpene, patchouli alcohol (4), as the trypanocidal constituents of this plant.

\section{Results and Discussion}

Dried herb of $P$. cablin was extracted with acetone under reflux and the extract, which showed strong in vitro trypanocidal activity, ${ }^{2)}$ was separated by repeated column chromatography under the guidance of trypanocidal activity to give compounds $\mathbf{1} \mathbf{- 3}$ as the main trypanocidal constituents together with a known sesquiterpene which was identified with patchouli alcohol $(4)^{4)}$ by comparison of the spectral data to those reported.

Compound 1 was obtained as a colorless oil. The molecular formula was determined as $\mathrm{C}_{15} \mathrm{H}_{24} \mathrm{O}_{2}$ by high-resolution chemical ionization mass spectrum (HR-CI-MS $\mathrm{m} / \mathrm{z}$ : $237.1862[\mathrm{M}+\mathrm{H}]^{+}$, Calcd for $\left.\mathrm{C}_{15} \mathrm{H}_{25} \mathrm{O}_{2}: 237.1854\right)$. The ${ }^{1} \mathrm{H}-$ NMR spectrum showed the presence of three methyls $\left(\delta_{\mathrm{H}}\right.$ $\left.0.87, \mathrm{~d}, J=7.0 \mathrm{~Hz} ; \delta_{\mathrm{H}} 1.40, \mathrm{~s} ; \delta_{\mathrm{H}} 1.60, \mathrm{~s}\right)$, an exo-methylene ( $\delta_{\mathrm{H}} 4.72$ and 4.73 , each brs) and an olefine $\left(\delta_{\mathrm{H}} 5.65\right.$, brs). The ${ }^{13} \mathrm{C}-\mathrm{NMR}$ spectrum showed that it had fifteen carbons with two double bonds $\left(\delta_{\mathrm{C}} 151.4,151.2,129.7,108.9\right)$. These data indicated that $\mathbf{1}$ is a sesquiterpene with two double bonds and two ring structures. As the ${ }^{13} \mathrm{C}$-NMR spectrum showed only one oxygenated carbon signal and the chemical shift ( $\left.\delta_{\mathrm{C}} 84.2\right)$ was relatively large, the oxygen function was estimated to be a hydroperoxy group. This was confirmed by a reduction of $\mathbf{1}$ with triphenylphosphine. Treatment of $\mathbf{1}$ with triphenylphosphine gave a sesquiterpene alcohol (1a), whose ${ }^{1} \mathrm{H}$ - and ${ }^{13} \mathrm{C}-\mathrm{NMR}$ spectra, together with its optical rotation, were in good agreement with those of a known sesquiterpene alcohol, (-)-guaia-1,11-dien-10 $\alpha$-ol. ${ }^{5)}$ Thus the structure of 1 was concluded to be $10 \alpha$-hydroperoxyguaia-1,11-diene.
Compound 2 was obtained as a colorless oil. This compound has the same molecular formula $\left(\mathrm{C}_{15} \mathrm{H}_{24} \mathrm{O}_{2}\right)$ with that of 1 (HR-CI-MS $m / z: 237.1851[\mathrm{M}+\mathrm{H}]^{+}$, Calcd for $\mathrm{C}_{15} \mathrm{H}_{25} \mathrm{O}_{2}$ : 237.1854). The ${ }^{1} \mathrm{H}-\mathrm{NMR}$ spectrum showed the presence of two methyls $\left(\delta_{\mathrm{H}} 0.76, \mathrm{~d}, J=7.4 \mathrm{~Hz} ; \delta_{\mathrm{H}} 1.60, \mathrm{~s}\right)$ and two exo-methylenes $\left(\delta_{\mathrm{H}} 4.70\right.$ and $4.73 ; 4.96$ and 4.97 , each br s). The ${ }^{13} \mathrm{C}$-NMR spectrum showed that it had fifteen carbons with two double bonds $\left(\delta_{\mathrm{C}} 151.6,151.2,115.6\right.$, 108.8). These data indicated that 2 is also a sesquiterpene with two double bonds and two ring structures. Since the ${ }^{13} \mathrm{C}$ NMR spectrum showed only one oxygenated carbon signal and its chemical shift ( $\left.\delta_{\mathrm{C}} 99.2\right)$ was very large, it was concluded to be a sesquiterpene hydroperoxide. Treatment of 2 with triphenylphosphine confirmed this conclusion giving a sesquiterpene alcohol (2a), whose ${ }^{1} \mathrm{H}$ - and ${ }^{13} \mathrm{C}-\mathrm{NMR}$ spectra, together with its optical rotation, were in good agreement with those of a known sesquiterpene alcohol, (+)-guaia$10(15), 11$-dien- $1 \alpha$-ol. ${ }^{5)}$ Thus the structure of 2 was concluded to be $1 \alpha$-hydroperoxy-guaia-10(15),11-diene. A small amount of $2 \mathbf{a}$ was also obtained from the extract.

Compound 3 was obtained as a colorless oil. This compound also has the molecular formula of $\mathrm{C}_{15} \mathrm{H}_{24} \mathrm{O}_{2}$ (HR-CIMS $m / z: 237.1860[\mathrm{M}+\mathrm{H}]^{+}$, Calcd for $\left.\mathrm{C}_{15} \mathrm{H}_{25} \mathrm{O}_{2}: 237.1854\right)$. The ${ }^{1} \mathrm{H}$ - and ${ }^{13} \mathrm{C}$-NMR spectra indicated that it is a sesquiterpene hydroperoxide with two double bonds and two ring structures. Treatment of $\mathbf{3}$ with triphenylphosphine gave a sesquiterpene alcohol (3a), whose ${ }^{1} \mathrm{H}$ - and ${ }^{13} \mathrm{C}-\mathrm{NMR}$ spectra, together with its optical rotation, were in good agreement with those of a known sesquiterpene alcohol, (-)-guaia1(10),11-dien-15 $\alpha$-ol. ${ }^{6}$ ) Thus the structure of 3 was concluded to be $15 \alpha$-hydroperoxy-guaia-1(10),11-diene.

The minimum lethal concentrations (MLCs) of the hydroperoxides $\mathbf{1}-\mathbf{3}$ against epimastigotes of Trypanosoma cruzi were $0.84 \mu_{\mathrm{M}}$ (1), $1.7 \mu \mathrm{M}$ (2), $1.7 \mu \mathrm{M}$ (3). We have reported the isolation and trypanocidal activity of monoterpene hydroperoxides from Laurus nobilis ${ }^{7)}$ and Chenopodium ambrosioides. ${ }^{8)}$ In these cases, the corresponding monoterpene

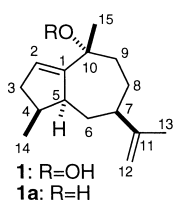

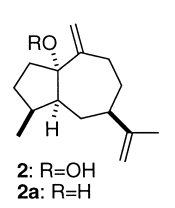
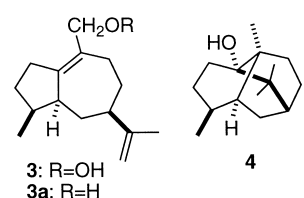

* To whom correspondence should be addressed. e-mail: ghonda@pharm.kyoto-u.ac.jp

(C) 2004 Pharmaceutical Society of Japan 
alcohols did not show trypanocidal activity. In agreement with these results, the activity of the alcohols $\mathbf{1 a - 3 a}$ and patchouli alcohol (4) were very weak (MLC $>200 \mu \mathrm{M})$. Thus the trypanocidal activity of the sesquiterpene hydroperoxides is ascribable to the hydroperoxy function. Hydroperoxides are unstable to steam-distillation, ${ }^{8)}$ and it may be one of the reasons that hydroperoxides $\mathbf{1}-\mathbf{3}$ have not been found in the essential oils of this plant.

\section{Experimental}

General Experimental Procedures Optical rotations were determined on a JASCO DIP-370 polarimeter. IR spectra were measured on a Shimadzu FTIR-8700 spectrometer. ${ }^{1} \mathrm{H}$ - and ${ }^{13} \mathrm{C}$-NMR spectra were measured on a JEOL JNM-LA500 spectrometer with tetramethylsilane (TMS) as an internal standard, and chemical shifts are given in $\delta$ values. Mass spectra were measured on a JEOL JMS-HX/HX110A spectrometer. Gel permiation chromatography (GPC) was performed on JAI-508 system with JAIGEL-H1 and $\mathrm{H} 2$ columns.

Plant Materials Dried herb of $P$. calbin (hoac huong) was purchased from a market in Ho Chi Min city in June 2000. A voucher specimen (ESMC225) was deposited at the Experimental Station of Medicinal Plants, Graduate School of Pharmaceutical Sciences, Kyoto University.

Extraction and Isolation Dried herb of $P$. calbin $(2 \mathrm{~kg})$ was extracted with acetone under reflux $(3 \mathrm{~h} \times 3$ times $)$ and the extract was concentrated under reduced pressure to give $149.9 \mathrm{~g}$ of residue. A part of the residue $(20 \mathrm{~g})$ was applied to a silica gel column and eluted with hexane-AcOEt $(19: 1,1: 1)$ and $\mathrm{MeOH}$ to give eight fractions (fraction, weight (g), MLC $(\mathrm{mg} / \mathrm{ml})$ : fr. $1,4.90,100$; fr. $2,0.28,50$; fr. $3,0.21,3.13$; fr. $4,4.42,1.56$; fr. $5,0.59,0.78$; fr. $6,0.97,12.5$; fr. $7,5.01,25$; fr. $8,3.40,>100$ ). Fraction 5 was fractionated by silica gel column chromatography (CC) with hexane-acetone $(8: 1)$ to give seven fractions (fraction, weight (mg), MLC $(\mu \mathrm{g} / \mathrm{ml}):$ fr. $5-1,40,25$; fr. $5-2,90,50$; fr. $5-3,24,12.5$; fr. $5-4,68,0.78$; fr. $5-5,234,0.20$; fr. 5-6, 97, 1.56; fr. 5-7, 52, 12.5). The most active fraction (fr. 5-5) was purified with benzene-diethylether $(30: 1)$ to give compound 1 $(64 \mathrm{mg})$. Fraction 5-4 was separated with Lobar ${ }^{\circledR}$ Si-60 (benzene$\mathrm{AcOEt}=39: 1)$ and $\mathrm{Lobar}^{\mathbb{R}} \mathrm{RP}-18(85 \% \mathrm{MeOH})$ column chromatography to give compound 2a $(10 \mathrm{mg})$. A fraction corresponding to fr. 4, which was prepared from $40 \mathrm{~g}$ of the extract, was separated by silica gel CC with benzene-diethylether $(30: 1)$ to give four fractions (fr. $4-1,0.24 \mathrm{~g}$; fr. 4-2, $0.57 \mathrm{~g}$; fr. 4-3, $2.60 \mathrm{~g}$; fr. 4-4, $2.08 \mathrm{~g}$ ). Fraction 4-3 and fr. 4-4 contained patchouli alcohol (4) as the major constituent. The most active fraction (fr. 4-2, MLC $0.39 \mu \mathrm{g} / \mathrm{ml}$ ) was separated by Lobar ${ }^{\circledR}$ Si-60 CC (benzene) and further fractionation of the major fraction $(187 \mathrm{mg}$ ) by GPC (benzene) gave four fractions (fr. 4-2-1, $42 \mathrm{mg}$; fr. 4-2-2, $65 \mathrm{mg}$; fr. 4-2-3, $34 \mathrm{mg}$; fr. 4-2-4, $26 \mathrm{mg})$. Purification of a part of fr. 4-2-2 $(30 \mathrm{mg})$ with Lobar $^{\mathbb{B}}$ Si-60 CC (hexane-acetone $=8: 1$ ) gave compound $3(6 \mathrm{mg})$. Repeated separation of $\mathrm{fr}$. 4-2-4 with Lobar ${ }^{\mathbb{R}} \mathrm{Si}-60 \mathrm{CC}$ (hexane-acetone $=10: 1$ and $20: 1$ ) gave compound $2(12 \mathrm{mg})$.

Compound 1: Colorless oil, $[\alpha]_{\mathrm{D}}+24.5^{\circ}\left(c=0.35\right.$, EtOH). IR $(\mathrm{KBr}) \mathrm{cm}^{-1}$. 3325, 2931, 2874, 1709, 1643, 1447, 1373. HR-CI-MS m/z: 237.1862 $\left([\mathrm{M}+\mathrm{H}]^{+}\right.$, Calcd for $\left.\mathrm{C}_{15} \mathrm{H}_{25} \mathrm{O}_{2}: 237.1854\right)$. CI-MS $m / z(\%): 237\left([\mathrm{M}+\mathrm{H}]^{+}\right.$, 36), 219 (60), $203(100) .{ }^{1} \mathrm{H}-\mathrm{NMR}\left(\mathrm{C}_{6} \mathrm{D}_{6}, 500 \mathrm{MHz}\right) \delta: 6.84(1 \mathrm{H}$, br s, $\mathrm{OOH}), 5.65(1 \mathrm{H}$, br s, H-2), 4.73 and $4.72($ each $1 \mathrm{H}$, br s, H-12), $2.47(1 \mathrm{H}$, m, H-5), 2.17 (1H, m, H-4), $2.11(1 \mathrm{H}$, ddd, $J=15.6,7.7,2.8 \mathrm{~Hz}, \mathrm{H}-3), 1.92$ $(1 \mathrm{H}$, br t $J=11.6 \mathrm{~Hz}, \mathrm{H}-7), 1.86-1.79(3 \mathrm{H}, \mathrm{m}, \mathrm{H}-3,9), 1.72(1 \mathrm{H}, \mathrm{brd}$, $J=12.5 \mathrm{~Hz}, \mathrm{H}-6), 1.62(1 \mathrm{H}, \mathrm{m}, \mathrm{H}-8), 1.60(3 \mathrm{H}, \mathrm{s}, \mathrm{H}-13), 1.40(3 \mathrm{H}, \mathrm{s}, \mathrm{H}-15)$ $1.12(1 \mathrm{H}$, br q, $J=11.6 \mathrm{~Hz}, \mathrm{H}-8), 1.03(1 \mathrm{H}, \mathrm{q}, J=12.5 \mathrm{~Hz}, \mathrm{H}-6), 0.87(3 \mathrm{H}, \mathrm{d}$, $J=7.0 \mathrm{~Hz}, \mathrm{H}-14) .{ }^{13} \mathrm{C}-\mathrm{NMR}\left(\mathrm{C}_{6} \mathrm{D}_{6}, 125 \mathrm{MHz}\right) \delta: 151.4(\mathrm{C}-11), 151.2(\mathrm{C}-1)$, 129.7 (C-2), 108.9 (C-12), 84.2 (C-10), 50.1 (C-7), 47.1 (C-5), 39.3 (C-4), 38.4 (C-3), 37.5 (C-9), 35.3 (C-6), 29.6 (C-8), 23.1 (C-15), 20.7 (C-13), 15.4 (C-14). ${ }^{1} \mathrm{H}-\mathrm{NMR}\left(\mathrm{CDCl}_{3}, 500 \mathrm{MHz}\right) \delta: 7.13(1 \mathrm{H}, \mathrm{brs}, \mathrm{OOH}), 5.89(1 \mathrm{H}$, br s), 4.67 and 4.64 (each $1 \mathrm{H}, \mathrm{brs}), 2.56(1 \mathrm{H}, \mathrm{m}), 2.37(2 \mathrm{H}, \mathrm{m}), 2.02(2 \mathrm{H}$, $\mathrm{m}), 1.87-1.72(4 \mathrm{H}, \mathrm{m}), 1.70(3 \mathrm{H}, \mathrm{s}), 1.47(3 \mathrm{H}, \mathrm{s}), 1.19(1 \mathrm{H}$, br q, $J=11.3 \mathrm{~Hz}), 1.04(1 \mathrm{H}, \mathrm{q}, J=12.8 \mathrm{~Hz}), 1.00(3 \mathrm{H}, \mathrm{d}, J=6.7 \mathrm{~Hz}) .{ }^{13} \mathrm{C}-\mathrm{NMR}$ $\left(\mathrm{CDCl}_{3}, 125 \mathrm{MHz}\right) \delta$ : 151.5 (C-11), $150.5(\mathrm{C}-1), 130.5$ (C-2), 108.5 (C-12), 84.8 (C-10), 49.9 (C-7), 46.8 (C-5), 39.3 (C-4), 38.3 (C-3), 37.1 (C-9), 35.0 (C-6), 29.2 (C-8), 22.7 (C-15), 20.7 (C-13), 15.4 (C-14).

Reduction of 1 with Triphenylphosphine Compound $1(11 \mathrm{mg})$ dissolved in diethylether $(5 \mathrm{ml})$ was treated with triphenylphosphine at room temperature for $15 \mathrm{~min}$. The mixture was concentrated and the residue was separated on silica gel (benzene-diethylether $=30: 1)$ to give $1 \mathrm{a}(9 \mathrm{mg})$.
(-)-Guaia-1,11-dien-10 $\alpha$-ol (1a): White solid, mp $117-118^{\circ} \mathrm{C}$ (lit. ${ }^{5)}$ $\left.118.5^{\circ} \mathrm{C}\right),[\alpha]_{\mathrm{D}}-66.1^{\circ}\left(c=0.40, \mathrm{CHCl}_{3}\right)\left(\right.$ lit. $\left.^{5)}-79.2^{\circ}, c=0.71, \mathrm{CHCl}_{3}\right)$.

Compound 2: Colorless oil, $[\alpha]_{\mathrm{D}}+71.8^{\circ} \quad(c=0.58$, EtOH $)$. IR $(\mathrm{KBr}) \mathrm{cm}^{-1}: 3418,2932,2870,1643,1450,1377$. HR-CI-MS $m / z: 237.1851$ $\left([\mathrm{M}+\mathrm{H}]^{+}\right.$, Calcd for $\left.\mathrm{C}_{15} \mathrm{H}_{25} \mathrm{O}_{2}: 237.1854\right)$. CI-MS $m / z(\%): 237\left([\mathrm{M}+\mathrm{H}]^{+}\right.$, 18), 219 (61), 203 (100). ${ }^{1} \mathrm{H}-\mathrm{NMR}\left(\mathrm{C}_{6} \mathrm{D}_{6}, 500 \mathrm{MHz}\right) \delta: 6.71(1 \mathrm{H}, \mathrm{brs}$, $\mathrm{OOH}$ ), 4.97 and 4.96 (each $1 \mathrm{H}$, br s, H-15), 4.73 and 4.70 (each $1 \mathrm{H}$, br s, H12), $2.36(1 \mathrm{H}, \mathrm{m}, \mathrm{H}-4), 2.33(1 \mathrm{H}, \mathrm{dd}, J=13.0,2.0 \mathrm{~Hz}, \mathrm{H}-9), 2.25(1 \mathrm{H}, \mathrm{m}, \mathrm{H}-$ 2), $2.14(1 \mathrm{H}$, ddd, $J=13.0,5.1,2.9 \mathrm{~Hz}, \mathrm{H}-9), 1.97(1 \mathrm{H}, \mathrm{brt}, J=11.1 \mathrm{~Hz}, \mathrm{H}-$ 7), $1.90-1.83(4 \mathrm{H}, \mathrm{m}, \mathrm{H}-3,5,6,8), 1.60(3 \mathrm{H}, \mathrm{s}, \mathrm{H}-13), 1.57(1 \mathrm{H}, \mathrm{brd}$, $J=14.7 \mathrm{~Hz}, \mathrm{H}-2), 1.30(1 \mathrm{H}, \mathrm{qd}, J=12.5,2.9 \mathrm{~Hz}, \mathrm{H}-8), 1.18(1 \mathrm{H}, \mathrm{m}, \mathrm{H}-3)$, $1.09(1 \mathrm{H}, \mathrm{q}, J=11.3 \mathrm{~Hz}, \mathrm{H}-6), 0.76(3 \mathrm{H}, \mathrm{d}, J=7.4 \mathrm{~Hz}, \mathrm{H}-14) \cdot{ }^{13} \mathrm{C}-\mathrm{NMR}$ $\left(\mathrm{C}_{6} \mathrm{D}_{6}, 125 \mathrm{MHz}\right) \delta: 151.6(\mathrm{C}-11), 151.2(\mathrm{C}-10), 115.6(\mathrm{C}-15), 108.8(\mathrm{C}-12)$, 99.2 (C-1), 51.1 (C-5), 49.9 (C-7), 38.2 (C-8), 36.6 (C-4), 33.3 (C-2), 31.7 and 31.4 (C-3,9), 29.8 (C-6), 20.7 (C-13), 15.9 (C-14).

Reduction of 2 with Triphenylphosphine Compound $2(7 \mathrm{mg})$ dissolved in diethylether $(1.5 \mathrm{ml})$ was treated with triphenylphosphine at room temperature for $15 \mathrm{~min}$. The mixture was concentrated and the residue was separated on silica gel (benzene-diethylether $=30: 1)$ to give $\mathbf{2 a}(4 \mathrm{mg})$.

(+)-Guaia-10(15),11-dien-1 $\alpha$-ol (2a): White solid, mp $64-65^{\circ} \mathrm{C}$ (lit. ${ }^{5)}$ $\left.69.5^{\circ} \mathrm{C}\right),[\alpha]_{\mathrm{D}}+67.6^{\circ}\left(c=0.23, \mathrm{CHCl}_{3}\right)\left(\right.$ lit. $\left.^{5}+67.1^{\circ}, c=0.73, \mathrm{CHCl}_{3}\right)$.

Compound 3: Colorless oil, $[\alpha]_{\mathrm{D}}+7.3^{\circ}(c=0.23, \mathrm{EtOH})$. IR $(\mathrm{KBr}) \mathrm{cm}^{-1}$ : 3356, 2928, 2870, 1439, 1342. HR-CI-MS $m / z 237.1860\left([\mathrm{M}+\mathrm{H}]^{+}\right.$, Calcd for $\mathrm{C}_{15} \mathrm{H}_{25} \mathrm{O}_{2}:$ 237.1854). CI-MS $m / z(\%): 237\left([\mathrm{M}+\mathrm{H}]^{+}, 3\right), 219$ (100), 203 (64). ${ }^{1} \mathrm{H}-\mathrm{NMR}\left(\mathrm{CDCl}_{3}, 500 \mathrm{MHz}\right) \delta: 7.86(1 \mathrm{H}, \mathrm{s}, \mathrm{OOH}), 4.65$ and 4.64 (each $1 \mathrm{H}$, brs, H-12), 4.51 and 4.48 (each $1 \mathrm{H}, \mathrm{d}, J=10.7 \mathrm{~Hz}, \mathrm{H}-15), 2.55$ $(1 \mathrm{H}, \mathrm{m}, \mathrm{H}-5), 2.50(1 \mathrm{H}, \mathrm{m}, \mathrm{H}-2), 2.36-2.25(2 \mathrm{H}, \mathrm{m}, \mathrm{H}-2,9), 2.22(1 \mathrm{H}, \mathrm{br}$, $J=12.0 \mathrm{~Hz}, \mathrm{H}-9), 2.18-2.11(2 \mathrm{H}, \mathrm{m}, \mathrm{H}-4,7), 1.78-1.67(2 \mathrm{H}, \mathrm{m}, \mathrm{H}-3,8)$, $1.70(3 \mathrm{H}, \mathrm{s}, \mathrm{H}-13), 1.65(1 \mathrm{H}, \mathrm{m}, \mathrm{H}-6), 1.39(1 \mathrm{H}, \mathrm{m}, \mathrm{H}-3), 1.23(1 \mathrm{H}, \mathrm{br}$, $J=12.0 \mathrm{~Hz}, \mathrm{H}-8), 1.05(1 \mathrm{H}, \mathrm{q}, J=12.2 \mathrm{~Hz}, \mathrm{H}-6), 0.92(3 \mathrm{H}, \mathrm{d}, J=7.1 \mathrm{~Hz}, \mathrm{H}-$ 14). ${ }^{13} \mathrm{C}-\mathrm{NMR}\left(\mathrm{CDCl}_{3}, 125 \mathrm{MHz}\right) \delta: 152.4(\mathrm{C}-1), 152.0(\mathrm{C}-11), 127.4(\mathrm{C}-$ 10), 108.3 (C-12), 80.0 (C-15), 50.9 (C-7), 46.7 (C-5), 38.2 (C-4), 33.0 (C3), 32.2 (C-8), 32.0 (C-6), 31.1 (C-9), 29.9 (C-2), 20.8 (C-13), 15.3 (C-14).

Reduction of 3 with Triphenylphosphine Compound $3(9 \mathrm{mg})$ dissolved in benzene $(5 \mathrm{ml})$ was treated with triphenylphosphine at room temperature for $8 \mathrm{~h}$. The mixture was concentrated and the residue was separated on silica gel (benzene-diethylether $=19: 1)$ to give $\mathbf{3 a}(4 \mathrm{mg})$.

$(-)$-Guaia-1(10),11-dien-15 $\alpha$-ol (3a): Colorless oil, $[\alpha]_{\mathrm{D}}-8.3^{\circ}(c=0.15$, $\left.\mathrm{CHCl}_{3}\right)\left(\right.$ lit. $\left.\left.^{6}\right)-11.6^{\circ}, c=1.0, \mathrm{CHCl}_{3}\right)$.

Patchouli Alcohol (4): White solid, mp 37-38 ${ }^{\circ} \mathrm{C}$ (lit. ${ }^{7)}$ colorless needles, mp $\left.54-56^{\circ} \mathrm{C}\right),[\alpha]_{\mathrm{D}}-119^{\circ}\left(c=1.0, \mathrm{CHCl}_{3}\right)\left(\right.$ lit. $\left.^{7)}-124^{\circ}, c=0.22, \mathrm{CHCl}_{3}\right)$.

Trypanocidal Assay ${ }^{8)}$ Epimastigotes of Trypanosoma cruzi (Tulahuen strain) were kept in GIT medium (Wako) supplemented with hemin (12.4 $\mu \mathrm{M}$, Wako). The epimastigotes in GIT medium $(10 \mu \mathrm{l})$ were incubated with a test sample dissolved in EtOH $(5 \mu \mathrm{l})$ and autoclaved saline $(185 \mu \mathrm{l})$. After $24 \mathrm{~h}$ of incubation, the movement of epimastigotes was observed under a microscope $(\times 100)$. Each assay was performed in duplicate. Gentian violet, which is used to disinfect trypanosomes from transfusion blood in Latin America, is used as a positive control. MLC of gentian violet under this assay condition was $6.3 \mu \mathrm{M}$.

Acknowledgement This work was supported in part by Grants-in-Aid for Scientific Research (No. 11672101 and No. 11793018) from the Japan Society for the Promotion of Science.

\section{References}

1) "International Collation of Traditional and Folk Medicine," Vol. 4, ed. by Guo J.-X., World Scientific, Singapore, 2001, pp. 99-100.

2) Kiuchi F., Matsuo K., Itano Y., Ito M., Honda G., Qui T. K., NakajimaShimada J., Aoki T., Natural Medicines, 56, 64-68 (2002).

3) Bastien J. W., "The Kiss of Death, Chagas' Disease in the Americas," The University of Utah Press, Salt Lake City, 1998.

4) Ichikawa K., Kinoshita T., Sankawa U., Chem. Pharm. Bull., 37, 345348 (1989).

5) Ishihara M., Masatsugu Y., Uneyama K., Tetrahedron, 48, 1026510276 (1992).

6) Ishihara M., Tsuneya T., Shiga M., Uneyama K., Phytochemistry, 30, 3343-3347 (1991).

7) Uchiyama N., Matsunaga K., Kiuchi F., Honda G., Tsubouchi A., Shimada J., Aoki T., Chem. Pharm. Bull., 50, 1514-1516 (2002).

8) Kiuchi F., Itano Y., Uchiyama N., Honda G., Tsubouchi A., NakajimaShimada J., Aoki T., J. Nat. Prod., 65, 509-512 (2002). 